\title{
Analisis Pengelolaan Keuangan Desa Berdasarkan Peraturan Menteri Dalam Negeri No 20 Tahub 2018 (Studi Kasus Pada Desa Saleh Makmur Kecamatan Air Salek Kabupaten Banyuasin)
}

\author{
Yulianti ${ }^{1}$, Nurmala ${ }^{2}$, Hendry Saladin ${ }^{3}$ \\ ${ }^{1}$ Fakultas Ekonomi dan Bisnis Universitas PGRI Palembang, yuliyuli2899@Gmail.Com \\ ${ }^{2}$ Fak. Ekonomi dan Bisnis Universitas PGRI Palembang, nurmalabahamid@Gmail.Com \\ ${ }^{3}$ Fak. Ekonomi dan Bisnis Universitas PGRI Palembang, Hendrysaladin62@Gmail.Com
}

\begin{abstract}
ABSTRAK
Penelitian ini bertujuan untuk mengetahui bagaimana pengelolaan keuangan di Desa Saleh Makmur sesuai Peraturan Menteri Dalam Negeri No 20 Tahun 2018 tentang pengelolaan keuangan desaa. data yang digunakan adalah data primer dan sekunder, kemudian melakukan penganalisaan data dengan metode wawancara dan dokumentasl,pupulasi yang dipilih ialah laporan pengelolaan keuangan desa yang terkait tahap perencanaan, Tahap pelaksanaan, Tahap penatausahaan, Tahap pelaporan dan pertanggungjawaban dengan sampel yaitu laporan realisasi pelaksanaan APBDesa serta laporan pertanggungjawaban dengan sampel yaitu laporan realisasi pelaksanaan APBDesa danlaporan pertaggungjawaban tahun anggaran 2019-2020. Sehingga hasil yang di dapat pada riset ini menunjukkan bahwa pengelolaan keuangan di Desa Saleh Makmur dalam tahap perencanaan, tahap pelaksanaan, tahap penatausahaan, tahap pelaporan serta pertanggungjawaban pada tahaun 2019-2020 pada dasarnya menerapkan Peraturan Menteri Dalam Negeri No 20 Tahun 2018 dalam pengelolaan keuangan desa hanya ada beberapa yang perlu di perhatikan dalam tahap penatausahaan perlu di tingkatkan lagi, pada tahap pelaporan masih terlambat dalam penyampaian laporan realisasi pelaksanaan APBDesa nya serta Tahap Pertanggungjawaban juga masih terjadi keterlambatan dalam penyampaian laporan pertanggungjawaban dan realisasi pelaksanaan tidak diberi tahu kepada masyarakat baik melalui media informasi maupun papan pengumuman seperti memasang baliho.
\end{abstract}

Kata Kunci: Pengelolaan Keuangan Desa, Perencanaan, Pelaksanaan, Penatausahaan, Pelaporan, Pertanggungjawaban.

\begin{abstract}
This research activity aims to find out how financial management in Saleh Makmur Village is in accordance with Minister of Home Affairs Regulation No. 20 of 2018 concerning village financial management. the data used are primary and secondary data, then analyze the data using the interview method and the population documentation selected is the village financial management report related to the planning stage, implementation stage, administration stage, reporting and accountability stage with samples, namely reports on realization of APBDesa implementation and reports accountability with the sample, namely the report on the realization of the APBDesa implementation and the accountability report for the 2019-2020 fiscal year. So the results obtained in this research show that financial management in Saleh Makmur Village in the planning stage, implementation stage, administration stage, reporting stage and accountability in 2019-2020 is basically in accordance with the Regulation of the Minister of Home Affairs No. 20 of 2018 in financial management. there are only a few villages that need to be considered in the administrative stage, it needs to be improved again, at the reporting stage it is still late in submitting the report on the realization of the implementation of the APBDesa And the Accountability Stage there is also a delay in submitting the accountability report and the realization of the implementation is not notified to the public either through the media information and notice boards such as putting up billboards.
\end{abstract}

Keyword: Village Financial Management, Planning, Implementation, Administration, Reporting, Accontability. 


\section{A. PENDAHULUAN}

Peran penting dari pemerintah pusat dalam hal pemakaian keuangan mencangkup administrasi keuangan pusat, daerah serta Desa guna menambah otonomi desa menjadi desa mandiri yang mana harus dikerjakan disentarlisasi, tingkatkan kredibilitas melalui pensertaan serta bantuan baik saran maupun prasarana.

Sejalan dengan berlakunya undang-undang otonomi daerah dapat memberi kekuasaan untuk mengelola pemerintahan daerah yang lebih luas dan otentik. dengan adanya tugas, fungsi serta peran pemerintah pusat yang lebih luas dan pemerintah daerah bisa memiliki penghasilan yang bisa di anggap cukup serta memiliki sumber pembiayaan memadai untuk mengangkat urusan negara dalam kepentingan masyarakat setempat.

Permendagri No 20 Tahun 2018 dalam pengelolaan keuangan desa dijadikan acuan dalam pengelolaan keuangan desa sebab didalamnya telah mencangkup banyak prosedur mengelola keuangan desa yang mana dimulai tahap perencanaan, pelaksanaan, penatausahaaan, pelaporan dan pertanggungjawaban selanjutnya dalam Permendagri no 20 Tahun 2018 juga membahasa penting nya peran petugas desa serta kepala desa dalaam mengelola dana yang nominalnya bisa dikatakan cukup tinggi dan mengharuskan untuk mengelola keuangan desa dilaksananakan secara transaparansi, akuntabel, tertib serta di siplin anggaran.

Perencanaan pembangunan desa dimulai dari tahap perencanaan sebagai tahap pertama dalam pembangunan desa, tahap kedua yaitu pelaksanaan dalam anggaran yang telah disepakati ditahap sebelumnya dilaksanakan oleh pihak eksukusi dari anggaran dan belanja desa,sehubung dengan hal inisetiap melaksanakan anggaran sangat diperlukankefokusan supaya dalam organisasi tidak begitu saja menggunakan seluruh anggaran yang di peroleh. Tahap berikutnya yaitu penatausahaan ialah kegiatan yang dilaksanakan dengan teraturkedalam bidang keuangan sehinggadatanyata berhubungan langsung dengan keuangan.

Selanjutnya laporan ialah kegiatan yang dilaksanakan agar memberikan sesuatu yang bersangkutan dengan jumlah analisis pekerjaan selama1 tahun dengan era tertentu sebagai wujud pelaksanaan dalam kewajiban serta wewenang yang telah di berikan.

APBN ialah media politik yang digunakan pemerintah serta oposisidalam akuntansi. Peran anggarandalam mengelola organisasi sektor publik termaksud penggunaan keuangan yang berfungsi sebagai alat yang diperlukan organisasi perlu tau apa yang harus dilakukan serta arah politik apa yang harus di buat.

Menurut Sujarweni (2015:33) APBDes ialah tanggung jawab aparat pengelola desa memberikan laporan kepada masyarakat serta pemerintah atas segala kegiatan desa yang tersusun dalam pengelolaan keuangan desa berdasarkan anggaran yang tersedia dan digunakan.

Masalah lainnya yaitu pada partipasi masyaralat dalam musyawarah rencana pembangunan yang relatif masih bisa dikatakan rendah dan sering kali berdominan kepada para elit desa. Hal tersebut menyebabkan masyarakat kurang aktif dan andil dalam pembangunan desa sehingga masyarakat tidak bisa menyalurkan aspirasi mereka, sebgaian besar dari masyarakat tidak mengetahui apa saja rencana kerja pembangunan yang telah dibuat. Sesuai dengan uraian yang telah dijelaskan peneliti melaksanakan penelitian di Desa Saleh Makmur yang berdomisili di sekitar Kecamatan Air Salek Kabupaten Banyuasin dengan luas wilayah $\pm 8,53 \mathrm{Ha}$, dan jumlah penduduk kurang lebih 1.326 jiwa adapun bukti mengenai jumlah APBDesa 
tahun 2019 sebesar Rp.1.614.629,00 kemudian tahun 2020 sebanyak Rp. 1.496.579.962,00 diketahui jumlah anggaran Pendpatan dan Belanja Desa di Desa Saleh Makmur besarnya Anggaran yang didapat, memerlukan perencanaan yang baik serta pelaporan pertanggungjawaban yang baiksebab dengan laporan keuangan bisadikatakan handal di harapkan dapat dijadikan wujud tanggungjawab kepada masyarakat itu sendiri.

Pada tahun 2019 pendpatan dan realisasi pelaksanaan APBDesa tidak di informasilan secara tertulis maupun papan informasi atau pengumuman tentang saja belum menerapkan peraturan menteri dalam pengelolaan keuangan desa kemudian pada tahun 2020 Anggaran yang di dapat tidak diinformasikan kembali pelaporan pertanggungjawaban Perwujudan hasil pelaksanaan APBDesa berupa SPJ belum tersusun sehingga mengalami keterlambatan dalam pelaporannya. Masalah mendasar yang sering dihadapi pembangunan desa dihadapkan pada pembangunan infrastruktur yang tidak terencanan tujuan utama pembangunan biasanya agar pekerjaan yang dilakukan tidak menyentuh akar permasalahan di Desa.Pembangunan desa yang dilakukan dengan penerimaan anggran dengan penerimaan anggaran dengan cara mengadakan pelatihan budidaya perikanan, kewirausahaan, perkebunan pertanian yang dapat mendorong pendapatan masyarakat, namun untuk mendapat akses informasi tersebut membuat masyakat yang tinggal di desa masih bisa dikatakan berada di bawah garis kemiskinan.

Permasalahan pada penelitian ini adalah bagaimana pengelolaan keuangan di Desa Saleh Makmur Berdasarkan Peraturan Menteri Dalam Negeri No 20 Tahun 2018.

\section{B. KAJIANTEORI \\ 1) Pengertian Desa}

Menurut pendapat Nurcolis (2011:1) Desa merupakan pemerintah dengan otonomi adat oleh karena itu desa diartikan sebagai kesatuan masyarakat hukum berhak mengatur dan mengurus urusan masyarakat setempat berdasarkan hak asal usul.

Secara ringkas dapat simpulkan bahwa desa merupakan suatu kesatuan wilayah yang mana tidak berada dikota dan sistem pemerintahannya dikelola oleh kades.

\section{2) Pemerintah Desa}

UU No 6 Tahun 2014 menyatakan pemerintahan desa bertanggungjawab atas diselenggarakanya kepentingan masyarakat setempat dan pada pasal 55 nya disebutkan bahwa panitia desa berdasarkan pemerintah desa, BPD bekerja sama dengan Kades untuk membahas serta mengkoordinasikan rancangan perdes untuk mempertimbangkan keiinginan masyarakat dan memimpin mereka.

Aparat desa dalam mengolah keuangan desa mendukung otonomi desa yang membuat desa beroperasi secara normal untuk setiap perencanaanya pemerintah desa harus memberikan laporan ke Bupati lewat Camat kemudian masyarakat melalui BPD.

\section{3) Anggaran Pendapatan Belanja Desa}

Adapun anggaran penghasilan serta belanja Desa di dalam Permendagri ialah penerimaan Desa yang terdiri penghasilan asli desa, transfer serta penghasilan lainlain. Kemudian belanja desa atas penyelenggaraan pemerintah desa, melaksanakan 
pembangunan, membina masyarakat, menanggulangi musibah, kejadian serta keadaan mendesak. Terkahir pembiayaan yang meliputi pembiayaan diterima dan yang dikeluarkan.

\section{4) Pembangunan Desa}

Menurut undang-undang pengembangan Desa ialah upaya meningkatkan kehidupan masyarakat untuk sebesar besarnya iala kesejahteraan masyarakat dalam pembangunan yang dilaksankaan bagi pemerintah pusat, daerah provinsi maupun pemerintah daerah kota/kabupaten serta masyarakat selain itu dalam undang-undang desa terdapat susunan pembangunan desa termaksudsistem perencanaan, pelaksanaan, penatausahaan, pelaporan serta pertanggungjawaban.

\section{5) Pengelolaan Keuangan Desa}

Menurut Adisasmita (2011:21) Menyatakan pengelolaan yaitu menggerakan, mengorganisasikan serta mengarahkan usaha manusia memanfaatkan secara efektid material dan fasilitas untuk mencapau suatu tujuan. keuangan desa menurut undang-undang Desa Pasal 77 ayat 1 ialah segala wewenang serta kewajiban desa menimbulkanberbagai penghasilan, belanja, serta pembiayaan yang akan disusun pada pengelolaan keuangan desa itu sendiri.

\section{6) Perencanaan}

Menurut Herlambang (2013:45) menyatakan perencanaan ialah proses menguraikan urusan kesehatan yang terjadi dalamlingkungan masyarakat, melihat keperluan serta sumber daya yang tersedia, memastikan sasaran yang telah di tetapkan.

Jadi dapat disimpulkan bahwa perencanaan keuangan desa yaituproses dimana untuk melihat tujuan penggunaan dana yang telah diterima serta menyampaikan kke masyarakat agar masyarakat desa mengatahui apa saja rencana penggunaan dana desa serta ikut berpastisipasi dalam mengawal agar pelaksanaan pengelolaan keuangan desa itu berjalan dengan keinginan.

Adapun berkas-berkas perencanaan keuangan desa ialah meliputi RPJM, RKP Desa yang bertuju untuk rencana pembangunan desa tersusun secara berjangka mengikuti kesepakatan musyawarah desa, rancangan RKP Desa berupa penjabaran rencana pembangunan jangka menengah. Rencana pembangunan desa ditata berdasarkan keputusan dalam musywarah desa dalam pelaksanaanya paling lama bulan juni tahun berjalan.

\section{7) Pelaksanaan}

Pelaksanaan ialah rangkaian pekerjaan yang berkaitan pada pengeluaran uang negara dalam pelaksanaan dilapangan, adapun menurut Permendagri No 20 Tahun 2018 tentang pengelolaan keuangan desa pada pasal 43 ayat 1 pelaksanaan pengelolaan keuangan desa mencangkup penerimaan serta pengeluaran desa yang dii kerjakan melalui rekeing kas desa pada bank yang ditunjuk Bupati/Walikota. Pembangunan desa dilakukan pemerintah pusat, pemerintah daerah provinsi, pemerintah daerah kota/kabupaten dan pemerintah desa beserta masyarakat desa, (Kuncuro 2019:57).

Dengan kata lain pelaksanaan merupakan kegiatan yang telah direncanakan dan dianggarkan sebelum dilaksanakan dilapangan yang dibuat pemerintah desa yang di sepakati oleh kepala desa dan kaur keuangan dalam pengeluaran uang negara untuk mencapau suatu tujuan. 


\section{8) Penatausahaan}

Penatausahaan keuangan desa merupakan seluruh pencatatan yagkhusus dilaksanakan bendahara desa dan wajib mencatat seluruh transaksi yang telah dilaksanakan baik berupa penerimaan maupun pengeluaran dalam pencatatan kaur keuangan desa harus melakukan cara sitemastis serta kronologis dari kesepakatan, kemudian kas desa di catatake dalam buku kas umum berupa buku pembantu pajak dan buku pembantu bank. Buku kas pembantu pajak digunakan untuk mencatat setiap penerimaan uang dari pungutan pajak dan pencatatan pengeluaran berupa penyetoran pajak ke kas negara melalui transfer kemudian dicatat kedalam buku bank.

Menurut Peraturan Menteri Dalam Negeri No 20 Tahun 2018 tentang pengelolaan keuangan desa pada pasal 63 penatausahaan keuangan desa dilaksanakan bendahara mencatat penerimaan serta pengeluaran buku kas umum ditutup setiap akhir bulan merupakan suatu proses pembukuan dilakukan oleh kaur pemegang kewajiban desa dalam transaksi pengeluaran secara hati-hati sehingga dalam pengelolaan desa dapat berjalan dengan baik.

\section{9) Pelaporan}

Tahap pelaporan menurut Permendagri No 20 Tahun 2018 pasal 68 ayat 1 kepala desa memberikan laporan pelaksanaan APBDesa semester pertama pada Bupati/Walikota melalui Camat. Ayat 2 laporan sebagai mana yang dimaksud ayat 1 meliputi laporan pelaksanaan APBDesa serta Laporan realisasi kegiatan, ayat 3 kades menyusun laporan sebagaimana yang dimaksud paling lama minggu kedua bulan juli tahun berkenaan, laporan ialah kegiatan yang dilaksanakan perlu menyampaikan berbagai hal yang berkaitan atas hasil yang diterapkan 1 periode menjadibentuk pelaksanaan dan pertanggungjawaban mengenai kewajiban serta kekuasaan yang telah di berikan dandapat diartikan sebagai bentuk penyajian data mengenai sesuatu yang akan di informasikan. Selain itu pelaporan merupakan laporan atas rencana maupun kegiatan yang telah dilaksanakan berupa penyajian data mengenai sesuatu yang akan di pertanggungjawabkan berupa laporan kepada pihak yang bersangkutan.

\section{0) Pertanggungjawaban}

Menurut Hendry Simamora(2012:253) Suatu sistem penyampaian informasi berisi penjelasan data keuangan berdasarkan bidang pertanggungjawbaan dalam organisasi serta kategori perolehan dan beban yang bisa diatur pihak manejeman disebut pertanggung jawaban.

Dengan kata lain pertanggungjawaban adalah rangkaian kegiatan yang dalam penyampaikan laporan hasil kegiatan baik berupa penerimaan dan pengeluaran yang melekat dalam suatu kelompok itu sendiri, kepala desa wajib melaporkan pertanggungjawab itu kepada masyarakat desa agar tidak ada kejadian yang berhubungan dengan haltidak di inginkan seperti penyelewengan terhadap pengelolaankeuangan desa.

\section{Kerangka Pemikiran}

Menurut Sugiyono (2019:101) metode konseptual tentang bagaimana teori yang bersangkutan melalui macam-macam situasi yang telah diidentifikasikan menjadi masalah yang penting disebut kerangka berfikir. 
Adapun kerangka pemikiran dapat dilihat pada gambar 2.1 sebagai berikut

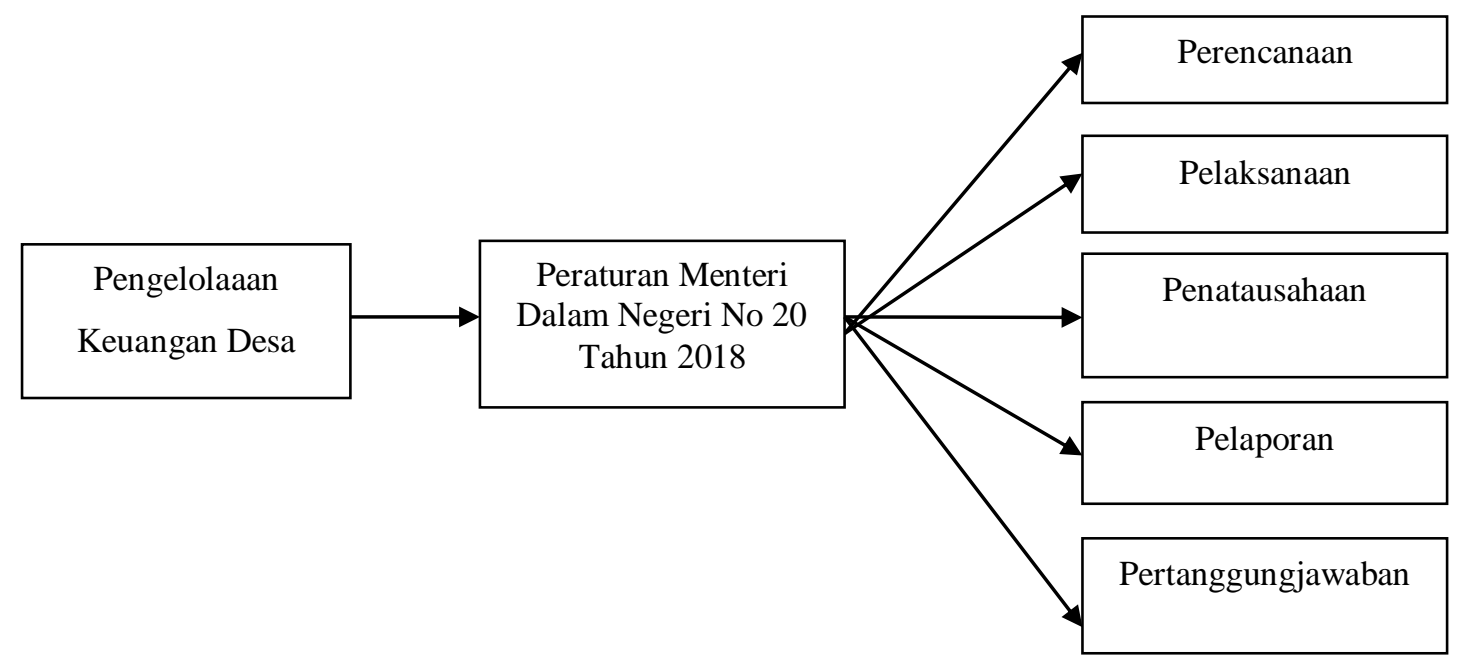

\section{Gambar Kerangka Pemikiran}

\section{Sumber: Data diolah, 2021}

Berdasarkan kerangka pemikiran penelitian ini dimulai dari pengelolaan keuangan di Desa Saleh Makmur Berdasarkan Peraturan Menteri Dalam Negeri No 20 Tahun 2018 yang terkait perencanaan, pelaksanaan, penatausahaan, pelaporan serta pertanggungjawaban.

Tahap perencanaan dalam mengelola keuangan dilihat dari Musyawarah Desa dalam penyusunan RPJM Desa, RKP Desa dan APBDesa harus sesuai dengan peraturan pemerintah dan undang-undang yang berlaku.Tahap pelaksanaan tahap ini dilihat dari transparansi pelaksanaan penggunaankeuangan desa yang mana dalam perencanaan program kegiatan yang telahditentukan dalam pelaksanaan pembangunan desa harus mengikuti jangka waktu yang telah di tetapkan, apakah sesuai dengan waktu dan dan ayang telahditetapkan atau tidak.Tahap penatausahaan yaitu proses dilihat dari pencatatan dilakukanbendahara desa untuk mencatat keseluruhan transaksi berupa penerimaan maupun pengeluaran dan harus dilakukan secara sistematis dan kronologi dari setiap transaksi.

Berikutnya dalam palaporan dan pertanggungjawaban pada tahapanini Kepala desa wajib menyajikan laporan pelaksanaan apbdes pada semester tahun berkenaan mengenai pelaporan dan pertanggung jawaban pada bupati /walikota.

\section{METODE PENELITIAN}

Metode yang digunakan pada penelitian iniadalah metode kualitatif dengan penjabaran deskriptif sebagai penelitian untuk mendapatkan data, menafsirkan serta mengklarifikasi data tersebut dengan peraturan pemerintah, penelitian ini instrumen yang digunakan yaitu wawancara dan dokumentasi.

Variabel penelitian yang digunakan ialah variabel independen terdiri dari pengelolaan keuangan desa yaitu Peraturan Menteri Dalam Negeri No 20 Tahun 2018 tentang pengelolaan keuangan desa berisi tahap perencanaa, pelaksanaan, panatausahaan, pelaporan serta pertanggungjawaban keuangan.

Populasi pada penelitian ini ialah laporan keuangan desa serta kegaiatan desa terkait proses perencanan, pelaksanaan, pelaporan serta pertanggungjawaban 
di Desa Saleh Makmur Kecamatan Air Salek Kabupaten Banyuasin. Adapun sampel dalam penelitian ini ialah laporan pelaksanaan serta pertanggungjawaban anggaran pendapatan belanja desa tahun 2019 \& 2020 .

Data yang dipakai ialah data primer dan sekunder, pengumpulan data dilakukan dengan wawancara dan dokumentasi Yang dilakukan langsung kepada narasumber yang terkait.

Teknik Analisis data yang dugunakan ialah statistik deskriptif yang merupakan penyajian data melalui analisis serta tabel untuk membuat perbandingan pengelolaan keuangan desa di Desa Saleh Makmur berdasarkan Peraturan Menteri Dalam Negeri No 20 Tahun 2018 terkait dalam perencanaan,pelaksanaan, penatausahaan, pelaporan serta pertanggungjawaban.

D. HASIL PENELITIAN DAN PEMBAHASAN

1. Perencanaan Pengelolaan Keuangan Desa Saleh Makmur Kecamatan Air Salek Kabupaten Banyuasin Tahun 2019-2020

Tabel Analisis Perbandingan Perencanaan Pengelolaan Keuangan Desa di Desa Saleh Makmur Berdasarkan Peraturan Menteri Dalam Negeri No 20 Tahun 2018

\begin{tabular}{|c|c|c|}
\hline $\begin{array}{c}\text { Permendagri } \\
\text { No } 20 \text { Tahun } 2018\end{array}$ & $\begin{array}{c}\text { Desa Saleh } \\
\text { Makmur Tahun 2019-2020 }\end{array}$ & Hasil \\
\hline $\begin{array}{l}\text { Pasal } 31 \\
\text { 1. Pengelolaan keuanga desa merupakan } \\
\text { penerimaan dan pengeluaran pemerintah } \\
\text { desa pada tahun anggaran tahun berkenaan } \\
\text { yang di anggarkan dalam APBDesa } \\
\text { 2. Sekretaris desa menyusun rancangan } \\
\text { peraturan desa tentang APBDesa } \\
\text { berdasarkan RKP Desa tahun berkenaan } \\
\text { 3. Materi yang memuat peraturan } \\
\text { Bupati/walikota sesuai dengan yang di } \\
\text { maksud pada ayat } 2 \text { a } \\
\text { 4. Rancangan APBDesa yang telah di susun } \\
\text { merupakan bahan penyusunan rancangan } \\
\text { peraturan desa tentang APBDesa }\end{array}$ & $\begin{array}{l}\text { Desa Saleh } \begin{array}{r}\text { Makmur untuk } \\
\text { perencanaan pengelolaan }\end{array} \\
\text { keuangan desa setiap } \\
\text { penerimaan serta pengeluaran } \\
\text { desa yang dianggarkan dalam } \\
\text { APBDesa. Kemudian sekdes } \\
\text { telah menyusun APBDesa yang } \\
\text { dimulai dengan musdus untuk } \\
\text { mengumpulkan aspirasi dari } \\
\text { masyarakat kemudian musdes } \\
\text { untuk menetukan pembangunna } \\
\text { apa yang akan di lakukan serta di } \\
\text { sahkan kemudian sekertaris desa } \\
\text { menyusun Rancangan APBDesa } \\
\text { sesuai RKP Desa yang berjalan } \\
\text { pada tahun tersebut dan } \\
\text { Rancangan APBDesa yang telah } \\
\text { disusun mejadi perdes tentang } \\
\text { APBDesa. }\end{array}$ & $\begin{array}{l}\text { Sudah } \\
\text { diterapkan }\end{array}$ \\
\hline
\end{tabular}




\begin{tabular}{|c|c|c|}
\hline $\begin{array}{l}\text { Pasal } 32 \\
\text { Sekdes menyampaikan rancangan peraturan } \\
\text { desa tentang APBDesa kepada kades } \\
\text { Rancangan peraturan desa tentang APBDesa } \\
\text { disampaikan kepala desa kepada BPD untuk } \\
\text { dibahas dan sepakati bersama dalam } \\
\text { musyawarah Desa Rancangan peraturan desa } \\
\text { tentang APBDesa yang disepakati bersama } \\
\text { paling lambat bulan oktober tahun berjalan } \\
\text { dalam hal BPD tidak menyepakati rancangan } \\
\text { Perdes tentang APBDesa yang disampaikan } \\
\text { kepala desa, pemerintah desa hanya } \\
\text { melakukan kegiatan yang berkenaan dengan } \\
\text { pengeluaran operasional penyelenggaraan } \\
\text { pemerintah desa dengan menggunakan pagu } \\
\text { sebelumnya. }\end{array}$ & $\begin{array}{l}\text { Di Desa Saleh Makmur sekdes } \\
\text { telah menyampaikan RAP Desa } \\
\text { kepada kadesserta } \\
\text { manyampaikan kepada BPD } \\
\text { untuk di bahas pada saat } \\
\text { musyawarah desa. Selanjutnya } \\
\text { sekdes menyampaikan APBDesa } \\
\text { kepada kades paling lama dibulan } \\
\text { oktober. }\end{array}$ & $\begin{array}{l}\text { Sudah } \\
\text { diterapkan }\end{array}$ \\
\hline $\begin{array}{l}\text { Pasal } 33 \\
\text { Atas kesepakatan bersama kepala desa dan } \\
\text { BPD kepala desa menyiapkan rancangan } \\
\text { peraturan desa mengenai penjabaran } \\
\text { APBDesa Sekretaris desa mengkoordinasikan } \\
\text { penyusunan rancangan peraturan kepala desa } \\
\text { Bupati/Walikota dalam melakukan evaluasi } \\
\text { berpedoman dengan panduan dengan } \\
\text { evaluasi rancangan peraturan desa tentang } \\
\text { APBDesa Penyampaian rancangan peraturan } \\
\text { desa tentang APBDesa }\end{array}$ & $\begin{array}{l}\text { Di Desa Saleh Makmur kades } \\
\text { telah menyiapkan rancangan } \\
\text { peraturan tentang penjabaran } \\
\text { APBDesa serta kades ditugaskan } \\
\text { untuk mengkoordinir rancangan } \\
\text { tersebut. }\end{array}$ & \\
\hline $\begin{array}{l}\text { Pasal } 37 \\
\text { Bupati/Walikota dapat mendelegasikan } \\
\text { evaluasi rancangan peraturan desa tentang } \\
\text { APBDesa kepada Camat. }\end{array}$ & $\begin{array}{l}\text { Bupati mendelegasikan } \\
\text { pertimbangan rancangan perdes } \\
\text { tentang APBDesa kepada Camat } \\
\text { serta evaluasi tersebut dilakukan } \\
\text { oleh Camat karna telah di beri } \\
\text { wewenang oleh Bupati. }\end{array}$ & $\begin{array}{l}\text { Sudah } \\
\text { Diterapkan }\end{array}$ \\
\hline $\begin{array}{l}\text { Pasal } 38 \\
\text { 1. Rancangan pedes tentang APBDesa yang } \\
\text { telah di evaluasi diputuskan oleh kepala } \\
\text { desa menjadi peraturan desa tentang } \\
\text { APBDesa } \\
\text { 2. Perdes tentang APBDesa ditetapkan paling } \\
\text { lama tanggal } 31 \text { desember tahun anggaran } \\
\text { sebelumnya } \\
\text { 3. Kepala desa menetapkan rancangan } \\
\text { peraturan kepala desa tentang penjabaran } \\
\text { APBDesa sebagai Peraturan Desa tentang } \\
\text { APBDesa. } \\
\text { 4. Kepala desa menyampaikan peraturan } \\
\text { desa tentang APBDesa dan Peraturan } \\
\text { Kepala Desa tentang penjabaran APBDesa } \\
\text { kepada }\end{array}$ & $\begin{array}{l}\text { Peraturan desa yang telah di } \\
\text { evaluasi / direvisi ditetapkan } \\
\text { menjadi tentang APBDesa serta } \\
\text { di sampaikan paling lambat } \\
\text { biasanya bulan Desember } \\
\text { kemudian kepala desa } \\
\text { menyampaikan perdes tersebut } \\
\text { pada Bupati biasanya maksimal } 7 \\
\text { hari setelah sepakati. }\end{array}$ & $\begin{array}{l}\text { Sudah } \\
\text { diterapkan }\end{array}$ \\
\hline
\end{tabular}




\begin{tabular}{|c|c|c|}
\hline $\begin{array}{l}\text { Pasal } 40 \\
\text { 1. Pemerintah desa hanya bisa } \\
\text { melakukan perubahan APBDesa } \\
\text { 2. Perubahan APBdesa hanya dapat } \\
\text { dilakukan } 1 \text { kali dalam } 1 \text { tahun } \\
\text { anggaran kecuali dalam keadaan luar } \\
\text { biasa } \\
\text { 3. Kriteria kedaan luar biasa di atur } \\
\text { dalam peraturan Bupati/Walikota } \\
\text { mengenai pengelolaan keuangan desa } \\
\text { 4. Peruabahan APBDesa ditetapkan } \\
\text { dengan perdes dan } \\
\text { mempedomani RKP Desa }\end{array}$ & $\begin{array}{l}\text { Kades melakukan perubahan } \\
\text { APBDesa jika diterapkan ada } \\
\text { penambahan dana sesuai dengan } \\
\text { perbub. }\end{array}$ & $\begin{array}{l}\text { Sudah } \\
\text { Diterapkan }\end{array}$ \\
\hline
\end{tabular}

Sumber: Data diolah, 2021

Berdasarkan hasil analisis serta tabel perbandingan secara menyeluruh proses perencanaan di Desa Saleh Makmur pada tahun 2019 serta 2020 secara menyeluruh telah menerapkan Permendagri No 20 tahun 2018. Perencanaan keuangan di Desa Saleh Makmur setiap proses harus mengikuti aturan di dalam Permendagri No 20 Tahun 2018 tentang pengelolaan keuangan desa, dalam perencanaan pembangunan infrastruktur pun sudah mengikuti prosedur peraturan yang ada seperti musyawarah dusun untuk mengumpulkan aspirasi masyarakat mengenai pembangunan apa yang akan dibuat untuk kemajuan desa serta bermanfaat bagi masyarakat setelah aspirasi dari masyarakat terkumpul selanjutnya dilakukan musyawarah desa yang mana dalam musyawarah ini proses Penentuan infrastruktur yang akan disepakati untuk dilaksanakan pada tahun 2019 rencana pembangunan sudah dilaksanakan seperti pembangunan jalan, pembuatan goronggorong, pembangunan jembatan penghubung dan masih ada pembangunan yang belum terlaksankan yang akan dilaksankan ditahun selanjutnya namun pada tahun 2020 tidak ada pembangunan dikarenakan adanya wabah covid 19 membuat dana desa untuk pembangunan dialihkan kepemberdayaan masyarakat kurang mampu mengadakan pengobatan gratis dan melakukan musyawarah untuk mematuhi protokol kesehatan.

Adapun di bandingkan dengan penelitian terdahulu yang dilakukan oleh Sinta P.Pratiwi tentang Analisis penerapan Peraturan Menteri dalam Negeri No 20 Tahun 2018 dalam proses perencanaan, proses pelaksanaan, proses penatausahaan, pelaporan serta pertanggungjawaban di Desa Puncangan diketahui bahwa dalam perencanaannya sudah memenuhi permendagri No 20 Tahun 2018 masih ada perbedaan pada rancangan perdes tentang APBDesa yang mana perlu disetujui selanjutnya yaitu bulan februari sedangkan dalam Permendagri dijelaskan bahwa rancangan perdes tentang APBDesa yang mana harus disetujui paling lama bulan oktober dengan hal tersebut perencanaan didesa puncangan belum sepenuhnya mengikuti prosedur yang ditetapkan. 


\section{Pelaksanaan Pengelolaan Keuangan Desa di Desa Saleh Makmur Kecamatan Air Salek Kabupaten Banyuasin Tahun 2019-2020}

\section{Tabel Perbandingan Pelaksanaan Pengelolaan Keuangan Desa di Desa Saleh Makmur Berdasarkan Peraturan Menteri Dalam Negeri No 20 Tahun 2018}

\begin{tabular}{|c|c|c|}
\hline $\begin{array}{l}\text { Peraturan Menteri Dalam } \\
\text { Negeri No } 20 \text { Tahun } 2018\end{array}$ & $\begin{array}{c}\text { Desa Saleh Makmur } \\
\text { Tahun 2019-2020 }\end{array}$ & Hasil \\
\hline $\begin{array}{l}\text { Pasal } 43 \\
\text { 1. Pelaksanaan pengelolaan } \\
\text { merupakan penerimaan dan pengeluaran } \\
\text { Desa yang dilaksanakan melalui rekening kas } \\
\text { desa } \\
\text { 2. Rekening kas desa dibuat oleh pemerintah } \\
\text { desa dengan spesimen tanda tangan kepala } \\
\text { desa dan kaur keuangan } \\
\text { 3. Desa yang belum memiliki pelayanan } \\
\text { perbankan diwilayahnya rekening kas desa } \\
\text { dibuka diwilayah terdekat. } \\
\text { Pasal } 45 \\
\text { 1. Kepala desa menugaskan kaur dan kasih } \\
\text { pelaksana kegiatan anggaran sesuai dengan } \\
\text { tugasnya menyusun DPA paling lama } 3 \text { hari } \\
\text { kerja setelah peraturan desa tentang } \\
\text { APBDesa dan perkades tentang penjabaran } \\
\text { APBDesa ditetapkan. } \\
\text { 2. DPA yang dimaksud terdiri atas: } \\
\text { a. Rencana kegiatan dan anggaran Desa } \\
\text { b. Rencana kerja kegiatan Desa dan } \\
\text { Rencana anggaran biaya. }\end{array}$ & $\begin{array}{l}\text { Di Desa Saleh Makmur telah } \\
\text { menyusun DPA dengan waktu } \\
\text { maksimal } 3 \text { hari setelah perdes } \\
\text { tentang APBDesa serta perkades } \\
\text { tentang penjabaran APBDesa. } \\
\text { DPA itu berupa Rancangan } \\
\text { pekerjaan dan anggaran rencana } \\
\text { kerja. }\end{array}$ & $\begin{array}{l}\text { Sudah } \\
\text { diterapkan }\end{array}$ \\
\hline $\begin{array}{l}\text { Pasal } 48 \\
\text { 1. Kaur keuangan menyusun rancangan RKP } \\
\text { berdasarkan DPA yang telah di setujui kepala } \\
\text { desa } \\
\text { 2. Rancangan RAK Desa disampaikan kepada } \\
\text { kepala Desa melalui sekertaris desa } \\
\text { 3. Sekretaris Desa melakukan verifikasi terhadap } \\
\text { rancangan RAK Desa yang diajukan kaur } \\
\text { keuangan } \\
\text { Kepala desa menyetujui rancangan RAK yang di } \\
\text { verifikasi sekretaris desa. }\end{array}$ & $\begin{array}{l}\text { Didesa saleh makmur bendahara } \\
\text { menyusun rancangan RAK } \\
\text { sesuai dengan DPA di } \\
\text { sampaikan oleh sekretaris desa } \\
\text { kepada kades setelah itu sekdes } \\
\text { melakukan verifikasi rancangan } \\
\text { RAK Desa selanjutnya kepala } \\
\text { desatinggalmenyetujui. }\end{array}$ & $\begin{array}{l}\text { Sudah } \\
\text { Diterapkan }\end{array}$ \\
\hline $\begin{array}{l}\text { Pasal } 49 \\
\text { RKP Desa yang memuat arus kas masuk serta } \\
\text { keluar dilakukan untuk mengatur penarikan dana } \\
\text { melalui rekening kas desa. }\end{array}$ & $\begin{array}{l}\text { RKP Desa meliputi arus kas } \\
\text { masuk dan keluar untuk menata } \\
\text { penarikan dana melalui rekening } \\
\text { kas desa. }\end{array}$ & $\begin{array}{l}\text { Sudah } \\
\text { Diterapkan }\end{array}$ \\
\hline $\begin{array}{l}\text { Pasal } 50 \\
\text { Arus kas yang diterima memuat semua } \\
\text { pendapatan Desa yang berasal dari pendapatan } \\
\text { asli desa, transfer dan pendapatan lain Setiap } \\
\text { pendapatan di dukung oleh bukti yang lengkap } \\
\text { dan sah. }\end{array}$ & \begin{tabular}{lrr}
\multicolumn{2}{l}{ Arus kas masuk meliputi } & seluruh \\
penghasilan & asli & desa, \\
penghasilan teransfer & serta \\
penghasilan lain-lain r dan & dash \\
penghasilan harus disertai \\
petunjuk yang lengkap serta sah.
\end{tabular} & $\begin{array}{l}\text { Sudah } \\
\text { Diterapkan }\end{array}$ \\
\hline
\end{tabular}

\section{Sumber :data diolah,2021}

Berdasarkan hasil analisis serta tabel perbandingan proses pelaksanaan di Desa Saleh Makmur pada tahun 2019-2020 sudah menerapkan Permendagri No 20 
Tahun 2018 tentang pengelolaan keuangan desa.

\section{Penatausahaan Pengelolaan Keuangan Desa di Desa Saleh Makmur Kecamatan Air Salek Kabupaten Banyuasin Tahun 2019-2020}

\section{Tabel Analisis Perbandingan Penatausahaan Pengelolaan Keuangan Desa di Desa Saleh Makmur Berdasarkan Peraturan Menteri Dalam Negeri No 20 Tahun 2018}

\begin{tabular}{|c|c|c|}
\hline $\begin{array}{c}\text { Permendagri } \\
\text { No } 20 \text { Tahun } 2018 \\
\end{array}$ & $\begin{array}{c}\text { Desa Saleh Makmur } \\
\text { Tahun 2019-2020 }\end{array}$ & Hasil \\
\hline $\begin{array}{l}\text { Pasal } 63 \\
\text { 1. Penatausahaan keuangan dilakukan oleh } \\
\text { kaur keuangan sebagai fungsi } \\
\text { kebendaharan. } \\
\text { 2. Penatausahaan dilakukan dengan } \\
\text { mencatat setiap penerimaan dan } \\
\text { pengeluaran dalam buku kas umum. } \\
\text { 3. Pencatatan pada buku kas umum ditutup } \\
\text { setiap akhir bulan. }\end{array}$ & $\begin{array}{l}\text { Di Desa Saleh Makmur } \\
\text { penatausahaan tidak dilakaukan oleh } \\
\text { bendahara saja, dalam } \\
\text { penatausahaan sudah dilaksanakan } \\
\text { pencatatan penerimaan maupun } \\
\text { pengeluaran kadalam buku kas } \\
\text { umum dan lakukan penutupan setiap } \\
\text { akhir bulan. }\end{array}$ & $\begin{array}{l}\text { Sudah } \\
\text { Diterapkan }\end{array}$ \\
\hline $\begin{array}{l}\text { Pasal } 64 \\
\text { kaur keuangan wajib membuat buku } \\
\text { pembantu kas umum yang terdiri dari: } \\
\text { a. Buku pembantu bank } \\
\text { b. Buku pembantu pajak } \\
\text { c. Buku pembantu panjar }\end{array}$ & & \\
\hline $\begin{array}{l}\text { Pasal } 65 \\
\text { Penerimaan di setorkan kerekening kas desa } \\
\text { dengan cara: } \\
\text { a. Disetorkan langsung ke bank oleh } \\
\text { pemerintah provinsi dan pemerintah } \\
\text { daerah kabupaten/kota } \\
\text { b. Disetorkan melalui bank lain, badan } \\
\text { lemabaga keuangan dan atau kantor pos } \\
\text { oleh piha ketiga Disetorkan oleh kaur } \\
\text { keuangan untuk penerimaan yang di } \\
\text { proleh dari pihak ketiga. }\end{array}$ & $\begin{array}{l}\text { kas umum pembantu bank dan buku } \\
\text { pembantu pajak }\end{array}$ & $\begin{array}{l}\text { Sudah } \\
\text { Diterapkan }\end{array}$ \\
\hline
\end{tabular}

Sumber: Data diolah,2021

Berdasarkan hasil analisis serta tabel perbandingan proses pengelolaan keuangan desa tahap penatausahaan di Desa Saleh Makmur pada tahun 2019-2020 sudah menerapkan Permendagri No 20 Tahun 2018 pelaporan disampaikan setiap akhir bulan hanya saja dalam penatausahaan masih harus di tingkatkan lagi dan dalam pembuatan buku kas umum yang maish terdiri dari buku pembanti bank dan pembantu pajak saja seharunya didalam permendagri buku kas umum itu terdiri dari buku kas bank, buku kas, buku kas pajak dan buku kas panjar. 


\section{Pelaporan Pengelolaan Keuangan Desa di Desa Saleh Makmur Kecamatan} Air Salek Kabupaten Banyuasin Tahun 2019-2020

Tabel Analisis Perbandingan Pelaporan Pengelolaan Keungan Desa di Desa Saleh Makmur Berdasarkan Peraturan Menteri

Dalam Negeri No 20 Tahun 2018

\begin{tabular}{|c|c|c|}
\hline $\begin{array}{c}\text { Permendagri } \\
\text { No } 20 \text { Tahun } 2018 \\
\end{array}$ & $\begin{array}{c}\text { Desa Saleh Makmur } \\
\text { Tahun 2019-2020 }\end{array}$ & Hasil \\
\hline $\begin{array}{l}\text { Pasal } 68 \\
\text { 1. Kepala desa menyampaikan laporan } \\
\text { pelaksanaan APBDesa semester } \\
\text { pertama kepada Bupati/Walikota } \\
\text { melalui Camat } \\
\text { 2. Laporan tersebut terdiri dari: } \\
\text { a. Laporan pelaksanaan APBDesa } \\
\text { b. Laporan realisasi kegiatan } \\
\text { 3. Kepala desa menyusun laporan } \\
\text { dengan cara menggabungkan seluruh } \\
\text { laporan paling lambat minggu kedua } \\
\text { bulan juli tahun berjalan. }\end{array}$ & $\begin{array}{l}\text { Di Desa Saleh Makmur tahun } 2019 \\
\text { telah menyampaikan laporan } \\
\text { pelaksanaan APBDesa semester } \\
\text { pertama pada Bupati melalui } \\
\text { camat namun di tahun } 2020 \text { masih } \\
\text { mengalami keterlambatan dalam } \\
\text { penyampaian nya dikarenakan } \\
\text { pemerintah desa dalam kegiatan } \\
\text { mengalami kualahan sehingga } \\
\text { dalma pelaporan tidak tepat pada } \\
\text { waktunya. }\end{array}$ & $\begin{array}{l}\text { Belum } \\
\text { diterapkan di } \\
\text { tahun } 2020\end{array}$ \\
\hline
\end{tabular}

Sumber: Data diolah, 2021

Berdasarkan hasil analisis sertaperbandingan diatas dalam pelaporan pengelolaan keuangan di Desa Saleh Makmur pada tahun 2019 sdah menerpakan permendagri namun di tahun 2020 belum menerapkan disebabkan pada saat penelitian melalukan wawancara belum ada laporan seluruh realisasi pelaksanaan.

Adapun hasil Penelitian Sinta P.Pratiwi di Desa pucangan dalam pelaporan berdasarkan hasil yang di dapat belum sesuai dikarenkaan pada saat penelitian melakukan penelitian belum cukup setengah tahun penelitian melakukan wawancara menyebabkan tidak ada laporan untuk semester pertama ataupun semester akhir.

\section{Pertanggungjawaban Pengelolaan Keuangan Desa di Desa Saleh Makmur Kecamatan Air Salek Kabupaten Banyuasin Tahun 2019-2020}

\section{Tabel Analisis Perbandingan Pertanggungjawaban Pengelolaan Keuangan Desa di Desa Saleh Makmur Berdasarkan Peraturan Menteri Dalam Negeri No 20 Tahun 2018}

\begin{tabular}{|c|c|c|}
\hline $\begin{array}{c}\text { Permendagri } \\
\text { No } 20 \text { Tahun } 2018\end{array}$ & $\begin{array}{c}\text { Desa Saleh Makmur } \\
\text { Tahun 2019-2020 }\end{array}$ & Hasil \\
\hline $\begin{array}{l}\text { Pasal } 70 \\
\text { 1. Kepala desa menyampaikan laporan } \\
\text { pertanggungjawaban realisasi APBDesa } \\
\text { kepada Bupati/Walikota melalui camat } \\
\text { setiap akhir tahun anggaran. } \\
\text { 2. Laporan pertanggungjawaban } \\
\text { disampaikan paling lambat } 3 \text { bulan } \\
\text { setelah akhir tahun anggaran } \\
\text { berkenaan yang di tetapkan dengan } \\
\text { peraturan desa. }\end{array}$ & $\begin{array}{l}\text { Di Desa Saleh Makmur kedes telah } \\
\text { menyampaikan laporan } \\
\text { pertanggungjawaban APBDesa di } \\
\text { tahun } 2019 \text { namun di tahun } 2020 \\
\text { nya masih mengalami keterlambatan } \\
\text { dalam penyusunan spj nya sehingga } \\
\text { membuat keterlamabatan dalam } \\
\text { penyampaian kepada Camat }\end{array}$ & \\
\hline
\end{tabular}




\begin{tabular}{|c|c|c|}
\hline Pasal 72 & & \\
\hline $\begin{array}{l}\text { 1. Laporan realisasi APBDesa } \\
\text { diinformasikan kepada masyarakat } \\
\text { melalui media informasi } \\
\text { 2. Informasi tersebut memuat: } \\
\text { a. Laporan realisasi APBDesa } \\
\text { b.Laporan realisasi kegiatan } \\
\text { c. Kegiatan yang belum selesai atau } \\
\text { tidak dilaksanakan } \\
\text { d.Sisa anggaran } \\
\text { Alamat pengaduan. }\end{array}$ & $\begin{array}{l}\text { Saleh Makmur tahun } 2019 \text { dan } 2020 \\
\text { laporan realisasi tidak di sampaikan } \\
\text { kepada masyarakat baik melaui } \\
\text { media maupun papan informasi } \\
\text { seperti baliho. }\end{array}$ & $\begin{array}{l}\text { Belum } \\
\text { Diterapkan }\end{array}$ \\
\hline
\end{tabular}

\section{Sumber: Data diolah, 2021}

Berdasarkan hasil analisis serta perbandingan proses pertanggungjawaban pengelolaan keuangan desa tahun 2019-2020 Desa Saleh Makmur belum menerapkan Permendagri No Tahun 2018 dikarenakan laporan realisasi yang dilaksanakan serta pertanggungjawaban tidak disampaikan kepada warga baik secara tertulis maupun media informasi sedangkan dalam Permendagri Pemerintah harus menyapaikan laporan pelaksanaan dan pertanggungjawaban kepada masyarakat yang terdiri dari laporan realisasi APBDesa pada kelompok masyarakat baik tertulis maupun media informasi.

\section{E. KESIMPULAN DAN SARAN}

\section{Kesimpulan}

Berdasarkan Hasil Analisis pengelolaan keuanga desa di Desa Saleh Makmur Berdasarkan Peraturan Menteri Dalam Negeri No 20 Tahun 2018 maka dapat di simpulkan sebagai berikut:

a) Pada tahap perencanaan Desa Saleh Makmur Tahun 2019 serta 2020 sebagian besar sudah menerapkan Peraturan Menteri Dalam Negeri No 20 Tahun 2018.guna memperoleh kesepakatan bersama dalam pembangunan desa dengan melakukan Musyawarah Dukuh, Musyawarah Desa, dalam menetapkan rancangan RPJM Desa. Kemudian tahap pelaksanaan tahun 2019 serta 2020 sudah menerapkan Permendagri No 20 Tahun 2018 tahap pelaksanaan yang mana sebelumnya telah di rencanakan dan ditetapkan dalam bentuk RPJM Desa kemudian pada tahap ini ialah melaksanakan apa saja infrastruktur yang akan di bangun dalam hal pembangunan desa yang tertuang di dalam RPJM Desa.

b) Pada tahap penatausahaan tahun 2019 maupun di tahun 2020 sudah menerpakan Permendagri No 20 Tahun 2018 hanya saja dalam penatausahaan bukan hanya bendahara desa yang bertugas dalam penatausahaan melainkan perangkat desa lainnya juga ikut membantu seperti sekretaris desa itu di sebabkan kurang nya pemahaman bendahara desa sehingga masih memerlukan bantuan perangkat lain. Selanjutnya Pada tahap pelaporan di tahun 2019 sudah menerapkan Permendagri No 20 Tahun 2018 hanya saja di tahun 2020 nya masih mengalami keterlambatan dalam penyampaian laporan realisasi semester pertama dan semester akhir atau kedua yang seharusnya disampaikan di bulan oktober tahun berjalan.

c) Terakhir Pada tahap pertanggungjawaban pengelolaan keuangan Desa Tahun 2019-2020 belum menerapkan Permendagri No 20 Tahun 2018 dikarenakan 
laporan realisasi pelaksanaan APBDesa serta laporan pertanggungjawaban tidak disampaikan pada masyarakat baik tercatat maupun media papan penjelasan seperti papan baliho.

\section{Saran}

Sesuai dengan hasil pembahasan serta kesimpulan diatas adapun saran sebagai berikut:

a) Pada tahap perencanaan diharapkan dapat dipertahankankemudian dalammusyawarah dan penetapan RPJM serta anggaran yang di terima sebaiknya di informasikan kepada masyarakat melalui papan informasi. untuk tahap pelaksanaan diharapkan dapat di tingkatkan lagi dan mengikutsertakan masyarakat dalampembangunan desa agar pembangunan desa dapat terselesaikan tepat waktu dan dalam pembangunan infrastruktur menyesuaikan dengan apa yang dibutuhkan oleh warga atau masyarakat. Kemudian tahap penatausahaan sebaiknya mengikuti acuan Permendagri No 20 Tahun 2018 dan bendahara desa diharapkan ditingkatkan lagi agar bekerja sesuai dengan tugasnya masing-masing.

b) Pada tahap pelaporan diharapkandapat ditingkatkan lagi sebaiknya setiap peyampaian laporan semester pertama dan akhir disampaikan tepat waktunya. Terakhir tahap pertanggungjawaban diharapkan dapat ditingkatkan lagi sebaiknya pelaporan realisasi pelaksanaan serta laporan tanggungjawab disampaikan ke warga / masyarakat melalui media informasi seperti memasang baliho agar masyarakat dapat membaca apa saja rencana kerja di Desa serta nantinya mereka berpartisipasi dalam menyelesaikan program-program yang telah disepakati.

\section{DAFTAR PUSTAKA}

Adisasmita, R. (2011). Pengelolaan Pendapatan dan Anggaran Daerah. Yogyakarta. Graha IImu.

Herlambang. (2013). Pengantar Manajemen . Yogyakarta: Gosyen Publishing.

Kuncoro, Mudrajat. (2019) Ekonomika Desa Teori, Strategi, dan Realisasi Pembangunan Desa. Yogyakarta: Sekolah Tinggi IImu Manajemen YKPN.

Nurcholis. (2011). Pertumbuhan dan Penyelenggaraan Pemerintah Desa. Jakarta: Erlangga.

Peraturan Menteri Dalam Negeri No 20 Tahun 2018 Tentang Pengelolaan Keuangan Desa. Jakarta.

Undang-Undang Nomor 6 Tahun 2014 Tentang Desa. Jakarta.

Simamora, H. (2012). Manajemen Sumber Daya Manusia Edisi 1. Yogyakarta: STIE YKPN Yogyakarta.

Sugiyono. (2019). Metode Peneliian Kualitatif, Kuantitatif dan R\&D. Bandung: Alfabeta.

Sujaweni, V. Wiratna. (2015). Otonomi Desa. Jakarta: PT. Raja Grafindo Persada. 